\title{
$\mathrm{PDA}$ 를 이용한 유아 원격 감시 시스템
}

\author{
이정익 ${ }^{*}$ \\ ${ }^{1}$ 인하공업전문대학 기계설계과
}

\section{The Remote Monitoring System for Baby using by PDA}

\author{
Lee, Jeong Ick ${ }^{1^{*}}$ \\ ${ }^{1}$ Dept. of Mechanical Design INHA Technical Design
}

\begin{abstract}
요 약 본 개발 시스템은 적외선 센서 네트워크 시스템을 통해 RS-232 통신 수신 데이터(각 인큐베이터의 온도, 습 도)를 얻고, 각 채널 당 각각의 사람에 대한 감시 시스템이 작동된다. 이 감시 시스템은 TCP/IP 통신을 통한 PDA 뿐 만이 아니라 개인용 컴퓨터에도 작동된다. 이 시스템은 LabVIEW와 PDA 모듈의 통신 함수에서 활성화되어 작동되 며, 다른 도구를 이용하는 것보다 처리시간이 상당히 절약된다.
\end{abstract}

\begin{abstract}
The developed system is captured by RS-232 telecommunication receiving data (temperature and humidity of each incubator) through radio frequency sensor network system and is made by monitoring system for one person collecting each channel data. This monitoring system is capable of monitoring not only PDA through TCP/IP telecommunication but also personal computer. This system is actively application on telecommunication function of LabVIEW and PDA module and is considerably saved in processing time than using in other tools.
\end{abstract}

Key Words : Baby Monitoring System, RF(Radio Frequency)

\section{1. 서론}

신생아 인큐베이터의 경우, 수시로 내부의 온도, 습도 및 각종 데이터를 기록하도록 되어 있다. 이런 데이터를 기록 할 때 의사나 간호사가 직접 가서 확인하는 불편함이 있기 때문에 원격 계측이 가능한 시스템이 필요하게 되었다[1]. 이미 이전에 연구됐던 원격 계측의 통신 방식으로는 Web 기 반이나 Bluetooth를 활용하는 연구가 있었[2]. 하지만 이러 한 연구들에는 인큐베이터의 이동성이나 채널수의 한계를 가지고 있는 문제점들이 있다. 이러한 문제점들을 해결하기 위하여 연구에 고안된 것이 Bluetooth와 $\mathrm{TCP} / \mathrm{IP}$ 를 원활하게 연결시켜줄 무선 주파수 센서(RF Sensor)이며, 본 연구에서 는 저 전력의 RF 센서 네트워크를 이용하여 시스템을 개발 하였다. 그리고 계측된 각종 정보에 대해 사용자가 보다 쉽 게 모니터링 하기 위해서 LabVIEW를 이용하여 모니터링 프로그램을 개발하였다. 특히, $\mathrm{PDA}$ 를 통한 베이비 케어 시 스템의 원격 관리에서는 LabVIEW PDA 모듈을 사용함으
로써 기존의 개발 툴인 $\mathrm{EVC}++$ 를 사용했을 때 나타나는 시 간적 전송문제를 해결할 수 있었다. 또한 개발된 원격 모니 터링 프로그램에 대한 안정성과 정확성을 평가하기 위해 성 능 평가 실험을 하였다.

본 연구논문은 날로 증대되어가는 병원 의료인들 가운데 서도 특정 전문직에 인력난과 경험자의 의료서비스를 생산 자동화를 통해 손쉽게 해결하고자 하는 목적으로 연구된 결 과이다. 기존의 이 분야의 연구에선 인력과 경험자의 조직 체계 변화, 의료인 수급의 비능률성으로 환자나 사용자 모 두에게 불편을 끼쳐왔으며 이와 같은 유비쿼터스 생활 환경 변화에 따른 자동화로의 변환은 감히 상상하지 못했던 것이 현실이다. 하지만, 본 연구에서는 휴대형 디바이스(hand held device)인 PDA[4,6]나 핸드폰 등에도 기술을 적용하여 누구나 친숙하고 손쉬운 작동법으로 온도, 습도 및 신생아 의 상태를 실시간 모니터링하여 신생아 상태를 원격으로 감 지하고 소수의 의료인으로 동일한 의료 서비스 질을 제공하 는데 큰 도움이 될 수 있도록 하였다.

*교신저자 : 이정익(jilee@inhatc.ac.kr)

접수일 09년 04월 30일수정일 (1차 09년 07월 27일, 2차 09년 08월 05일)

게재확정일 09년 08월 19일 


\section{2. 유아 원격 감시 시스템}

본 개발시스템은 유비쿼터스 환경이 의료분야에 적용 된 실제 사례를 보여주는 것으로 현재 의료분야에 실제 적용되는 사례를 보여주고 있다. 개발된 시스템은 RF[5] 센서 네트워크 시스템을 통해 수신되는 데이터(인큐베이터 내의 온도, 습도)를 RS-232 통신을 통하여 획득하고, 각 채 널의 데이터를 분리하여 한 눈에 모니터링 할 수 있는 시스 템이다. 본 시스템은 PC에서 뿐만 아니라 TCP/IP 통신을 통 하여 PDA에서도 모니터링 할 수 있다. 이 시스템은 LabVIEW의 통신 기능 및 PDA module을 적극 활용하였으 며, 연구결과 효과면에서는 Bluetooth를 사용하는 것보다 개발시간이 약 $1 / 3$ 이상 절약되는 결과를 얻었다[2].

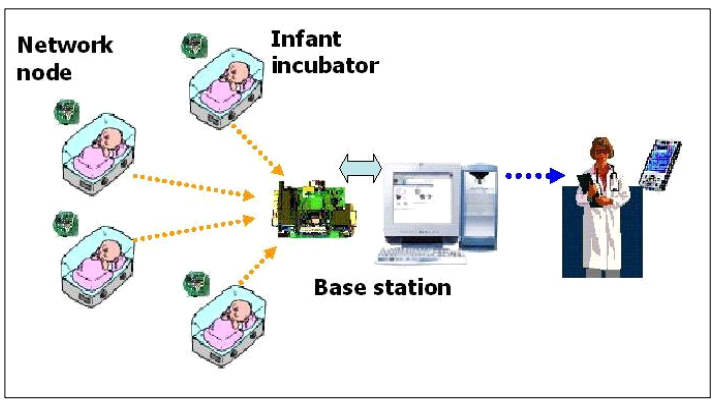

[그림 1] 시스템 구조도

개발된 유아 원격 감시 시스템에 대해 설명하겠다. 그림 1 은 개발하려는 시스템 구조도의 개략도이다. 구조도에 서 보는바와 같이 다수 개의 인큐베이터에서 센서들에 의해 제공되는 유아들의 온도, 습도 데이터를 데스크 탑 $\mathrm{PC}$ (Base Station)에 집결시켜 LabVIEW 모듈 및 TCP/IP 를 이용 관리자가 단말기로 실시간 확인 할 수 있는 시스 템으로 구성된다.

본 시스템에서 RF 센서 네트워크의 수신부로부터 RS-232 통신을 통해 PC로 데이터를 전송하도록 하였다. 데 이터 전송 속도는 $19200 \mathrm{bps}$ 로 설정하였다. RF 통신을 통해 들어오는 데이터는 36bytes로 구성된 하나의 데이터 패킷이 다. 이 안에는 많은 정보가 구체적으로 들어있고 그것을 각 각 분리해 낼 필요가 있다. 들어오는 데이터의 정확성 여부 를 위해 처음 Case문을 사용하였고, 들어온 36bytes의 데이 터 패킷에 대해 사용자에게 보여주기 위해 필요한 데이터만 뽑아냈다. 또, 각 데이터 값이 상위 바이트와 하위 바이트가 뒤집어 있었기 때문에 그것을 바꿔주는 함수를 간단히 하였 다. 분리된 데이터는 온도, 습도에 따라 계산을 하고 그래프 로 보여주게 된다. 또 그림 3 에서는 각각의 인큐베이터로부 터 수집된 온도, 습도 데이터들은 시간 당 30 개씩 모아서 히
스토그램 형태로 보여주어 의사들에게 또 다른 정보를 제공 하였다. 그리고 데이터를 텍스트로 저장하는 부분을 만들어 나중에 다시 확인하거나 $\mathrm{PDA}$ 를 $\mathrm{PC}$ 와 연결했을 때 자동으 로 파일이 복사되도록 하였다.

\section{3. 원격 모니터링 프로그램}

\subsection{PC용 감시 프로그램 개발}

본 연구에서는 인큐베이터로부터 계측된 각종 정보에 대 해 사용자가 보다 쉽게 모니터링 하기 위해서 LabVIEW를 이용하여 모니터링 프로그램을 개발하였다. 그림 2는 LabVIEW로 구성한 PC용 모니터링 프로그램을 나타낸다. 그림 3은 그림 2와 같은 LabVIEW로 작성된 $\mathrm{PC}$ 용 프로그램 이지만 온도, 습도에 대한 시간 당 30 개씩의 데이터를 모아 연속적으로 히스토그램의 형태로 표시해준 프론트 패널이 다. 그림 2의 경우는 4개의 셀(cell:1cell을 인큐베이터 한 개 로 취급)에 각각의 온도, 습도 센서들을 통해서 프로그램된 채널로 들어오는 데이터의 결과를 나타낸 것으로 프론트 패 널 상단부는 체온 30 도가 넘으면 연두색 등에서 빨강색 등 으로 바뀌어 점등되도록 되어 있으며, 하단부는 온도, 습도 에 대한 데이터를 그래프 형태로 나타낸 것이다. 그림 3은 시 간 당 30 개씩 모아진 데이터를 그래프 상에 히스토그램을 작성하여 보여주며 이는 또 다른 사용자 환경으로 모아진 유 아들의 온도, 습도에 대한 결과를 의사, 간호사들에게 제공 하는 역할을 한다. 또, 온도, 습도가 나타나는 범위가 다르므 로 $\mathrm{y}$ 축을 2 개로 하여 하나의 chart 안에서 데이터를 표현하 도록 하였다. 원칙적으로 인큐베이터 내부의 온도는 체온과 비슷한 수준에서 유지되지만 본 시스템은 일반 실험실에 측 정을 하였기 때문에 경고 알림 정도를 30 도로 설정하였다. 위 온도를 초과할 경우 프론트 패널의 LED가 빨강색으로 변하며, 경고음을 발생하도록 구성되어 있다.

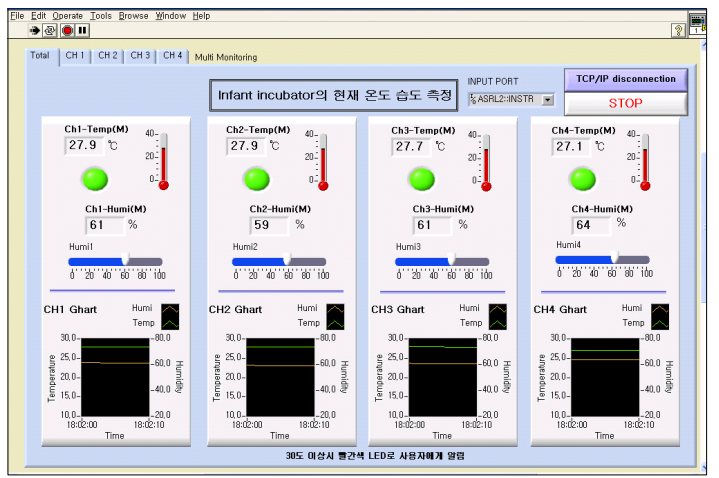

[그림 2] PC 프로그램 - 프론트 패널(1) 


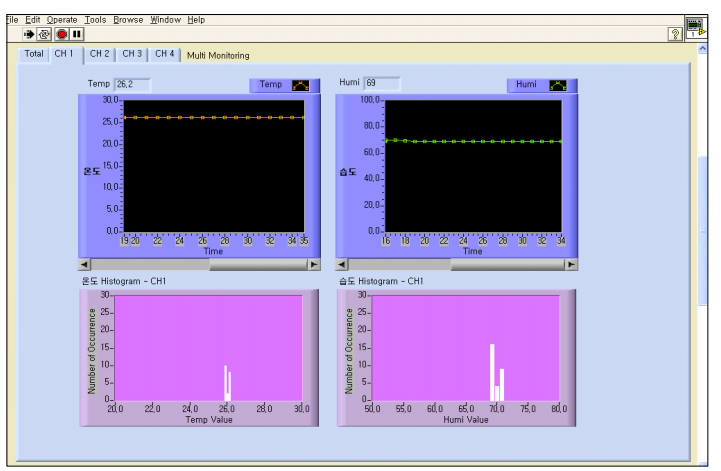

[그림 3] PC 프로그램 - 프론트 패널(2)

\subsection{PDA용 감시 프로그램 개발}

본 연구에서는 PDA를 통한 베이비 케어 시스템의 원격 관리를 위해 LabVIEW PDA 모듈을 사용하여 원격 모니터 링 프로그램을 개발하였다. 원격 모니터링 프로그램의 개발 에서는 기존의 개발 툴인 $\mathrm{EVC}++$ 를 이용하여 구성해 보았 지만 제공하는 함수가 제한적이고 실시간으로 동작하는 그 래프로 나타내기가 힘든 단점이 나타났다. 이 프로그램의 가장 큰 문제점은 시간지연이 생겨 데이터의 실시간 계측이 어려우며 무엇보다 시스템이나 필요한 데이터(본 연구에서 는 온도, 습도)가 바뀔 시는 프로그램 전체를 수정해야 하는 불편함이 있었다[2]. 그림 4는 LabVIE로 구성된 PDA용 모 니터링 프로그램의 블록 다이어그램이다. 각 채널에 대한 그래프 $\mathrm{x}$ 축에 실시간을 적용하기 위해 특성점(property node)를 사용하였고, 주(main) 화면에서 전체 채널을 모니 터링 할 수도 있고, 탭 컨트롤을 사용하여 각 채널을 분리해 모니터링 할 수 있도록 하였다. 또 TCP/IP 통신을 설정하여 채널, 온도, 습도의 데이터를 PDA로 전송한다. 본 시스템에 서 사용된 PDA는 Pocket PC 2003을 운영체제로 하고 있는 최신형의 $\mathrm{PPAQ}$ h2210이다. PDA의 TCP/IP 통신의 경우, 무 선 랜 기능이 내장되어 있지 않아서 SD type의 무선 랜 카드 를 사용하였다. PDA 인터페이스의 경우 PDA 화면의 제한 점 및 Chart의 제한으로 인해 온도에 대한 하나의 그래프만 을 보여주고 있다. 그리고 개발된 원격 모니터링 프로그램 에 대한 안정성과 정확성을 평가하기 위해 성능 평가 실험을 하였다. 그림 4는 휴대용 PDA에 나타난 유아 원격 감시 프 로그램의 사용 예 및 성능평가를 보여준다. 그림 4는 PC상 의 데이터들을 Wireless LAN으로 PDA에 구현한 PDA용 LabVIEW 프로그램을 보여주며 내부 프로그램은 데스크 탑 의 $\mathrm{PC}$ 데이터를 TCP/IP로 받아 PDA에 나타내는 역할을 하 도록 프로그램 되어 있다. 그림 4는 무선 랜을 통해 TCP/IP 통신으로 받은 결과를 PDA상에 보여주는 것으로 IP 및 Port 와 4개의 인큐베이터에 대한 정보가 실시간으로 디지털화 되어 나타난다. 특히, 말을 못하는 유아들에게 있어 가장 중
요한 정보인 온도에 대한 정보가 실시간 차트로 표시되고 30 도를 넘을 경우 우측 상단에 빨강색 시그널을 울려 모니터링 을 하는 의사, 간호사에게 실시간 통지가 가능하도록 하였 다. 이러한 기술은 기존의 Bluetooth를 사용할 때와는 달리 데이터의 지연 없이 필요에 따라 쉽게 화면을 구성하고, 정 확하면서도 간단하게 원하는 계측결과를 얻을 수 있었다. 이러한 이유로 본 연구에서 개발된 유아 원격 감시 시스템 프로그램의 우수성이 실험을 통해 입증되었다. 만일, 기존 의 Bluetooth 기술을 사용할 경우 본 개발 시스템과 같은 시 간 내에 10 개 이상의 데이터에 대한 히스토그램을 작성하기 가 쉽지가 않으며, 채널수의 한계로 동시에 여러 개의 인큐 베이터를 모니터링 할 수도 없으므로 유아 원격 감시 시스템 을 구성하기에는 적절치 못하다. 또한, 무선 $\mathrm{LAN}$ 을 이용할 경우 데이터의 처리속도는 TCP/IP에 비해 비교될 수 없을 만큼 빠른 속도로 처리될 수 있으나, 시스템 구축과 어느 일 정 규모 이상의 병원에서 사용이 용이 하므로 인력난에 시달 리는 중소형 병원 및 개인병원에는 Bluetooth를 범용적으로 사용하는 시스템의 적용이 훨씬 바람직하다고 생각된다. 본 연구에서 데이터 전송시 발생되는 노이즈에 대한 처리는 LabVIEW에서 제공되는 PDA 전용 주파수 대역 필터(band pass filter)를 이용하여 처리하였다.

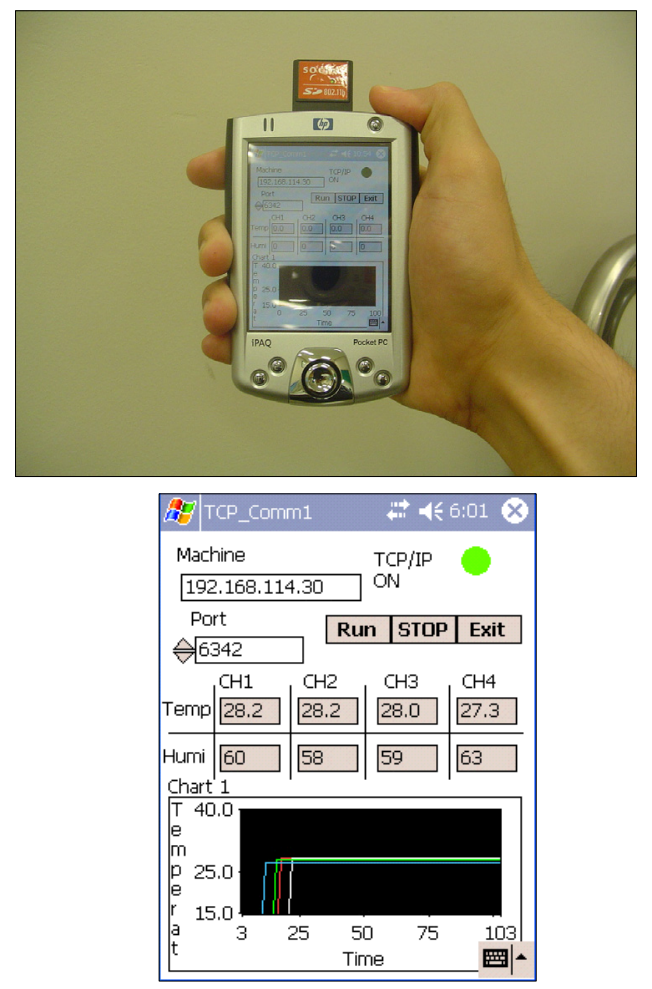

[그림 4] PDA 프로그램 - 프론트 패널 


\section{4. 결론}

PDA 모듈의 무선 랜을 이용한 유비쿼터스 개념하의 유아 모니터링 시스템을 구성하고 프로그램을 실험해본 결과 다음과 같은 결론을 얻었다.

1. 본 연구에서는 Bluetooth 및 $\mathrm{TCP} / \mathrm{IP}$ 기반의 $\mathrm{PDA}$ 에 적 용된 유아 원격 감시 프로그램을 통하여 유아 상태 모 니터링에 가장 필요한 온도, 습도를 실시간, 통계적 모 니터링을 통해 의료분야에 혁신적인 인력난과 정확한 통계분석이 가능한 시스템을 개발하였다. 또한, 본 시 스템은 그동안 특정, 전문적인 의료인들의 기술 및 경 험을 일반화하여 누구든지 손쉽게 이용, 적용이 용이 하도록 하였다.

2. 본 연구를 통해 $\mathrm{PDA}$ 나 각종 휴대 단말기를 활용하는 유비쿼터스 헬스케어나 홈오토메이션 등에도 쉽게 확 장 활용이 가능할 것으로 생각된다.

3. 시스템은 처음에 기존의 개발 툴인 $\mathrm{EVC}++$ 를 사용했 을 때 나타나는 시간적, 거리상의 전송문제를 TCP/IP 통신을 적용하여 해결하였다. 현재 TCP/IP 통신으로 획득한 데이터를 의사나간호사가 인터넷이 가능한 어 느 곳에 가더라도 데이터 확인이 가능하도록 제작하였 다.

4. 향후 PDA module 7.1의 탭 컨트롤을 사용하면 좀 더 개 선할 수 있을 것이며, 더 나아가 일반 윈도우에서의 LabVIEW 처럼 property node, 각종 색의 지원 및 chart 의 기능 개선이 된다면 한층 향상될 것으로 보인다. 현 재 시스템은 간단한 온도, 습도의 데이터이지만 앞으 로는 생체 신호를 바탕으로 한 데이터 획득이나 네트 워크시스템을 형성할 수 있을 것으로 보인다.

\section{참고문헌}

[1] Steve Mann, Hal Niedzviecki.,"Cyborg: Digital Destiny and Human Possibility in the Age of the Wearable Computer", Double day Canada, 2002.

[2] Christian Piguet.,"Low-Power Electronics Design", CRC Press, 2004.

[3] Mark Weiser, John Seely Brown, "Designing Calm Technology", 1995.

[4] 박용빈, 양해술, "모바일기기 PDA를 이용한 E-Learning Contents에 대한 XML 기반 검색시스템”, 한국산학기 술학회논문집, Vol. 10, No. 4, pp. 818-823, 2009.

[5] 김은환, 정용훈, 전문식, “홈 네트워크에서 RFID를
이용한 디바이스 간 디지털 콘텐츠 이동에 관한 연 구”, 한국산학기술학회논문집, Vol. 10, No. 2, pp. 351-357, 2009.

[6] 박주평, 홍진근, 한군희, 김기홍, "PDA 기반 무선 $\mathrm{AP}$ 의 위치 탐색 시스템 구현”, 한국산학기술학회논문집, Vol. 9, No. 4, pp. 952-957, 2008.

이 정 익(Jeong-Ick Lee)

[정회원]

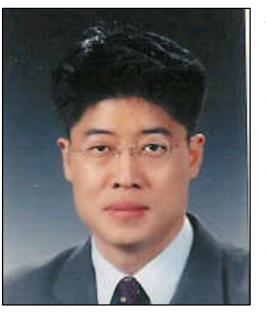

- 1991년 2월 : 한양대학교 공과대 학. 기계공학과 (공학사)

- 1993년 2월 : 한양대학교 공과대 학. 정밀기계공학과 (공학석사)

- 1999년 8월 : 한양대학교 공과대 학. 정밀기계공학과 (공학박사)

- 1993년. 1월 1999년 12월 : (주)대우전자. 중앙연구소 (선임 연구원)

- 2000년 3월 2007년 2월 : 용인송담대. 자동차기계설 계전공 (교수)

- 2007년 3월 현재 : 인하공전. 기계공학부. 기계설계 과 (교수)

<관심분야>

$\mathrm{CAD} / \mathrm{CAM} / \mathrm{CAE}$, 공장자동화, 생산자동화, 사출금형, 유 비쿼터스, MEMS, BIOMECHANICS 